\title{
Supply chain integration strategies in fast evolving industries
}

\author{
Ehsan Sabet \\ Wolfson School of Mechanical, Electrical and Manufacturing Engineering, \\ Loughborough University, Loughborough, UK \\ Nahid Yazdani \\ Department of Business and Economics, Loughborough University, \\ Loughborough, UK, and \\ Sander De Leeuw \\ Business School, Nottingham Trent University, Nottingham, UK and \\ Faculty of Economics and Business, Vrije Universiteit Amsterdam, \\ Amsterdam, The Netherlands
}

\begin{abstract}
Purpose - The purpose of this paper is to define the "fast evolving industry" (FEI) and its supply chain management (SCM) challenges. The authors review and structure the literature regarding integration strategies and implementation methods to develop a strategic decision-making framework for SCM in the FEI. Design/methodology/approach - The authors conduct a review of SCM literature, including supply chain strategy, supply chain integration (SCI), agile and responsive supply chain and SCM for innovative and fastchanging industries. The authors develop a conceptual model and a decision-making framework and use four mini cases to provide support for the model and framework.

Findings - The FEI, characterised by a high level of innovation and differentiation, short products/services lifecycle and high variety, is yet to be fully defined. Inherent uncertainty in FEI supply systems makes SCM in these industries a complex but strategic task for their managers. The framework and the model offered in this study, which employ a core competency concept and provide risk management strategies, offer a strategic tool for managers and scholars in the field to optimise their integration strategies and to operationalise integration decisions. Originality/value - Little research has been published on transferable and cross-industrial SCM in FEIs. This paper defines the FEI and its resource-related concerns and then offers a conceptual model and a strategic decision-making framework for SCI in FEIs.
\end{abstract}

Keywords Supply chain management, Supply chain strategy, Supply chain integration, Agile supply chain, Fast evolving industries, Responsive supply chain

Paper type Conceptual paper

\section{Introduction}

Fast evolving industries (FEIs) are industries characterised by high levels of innovation and differentiation (Humphrey and Schmitz, 2002), high-product/service variety and low-product/service life or replenishment cycles (Bilgen and Günther, 2010) and increasingly sophisticated customers (Stevenson and Spring, 2007). Applying this definition, one can observe that FEIs account for a large proportion of high added-value industries in developed countries, for example, electronics and telecommunications (Arnold, 1999), semiconductors (Brown et al., 2000), fast moving consumer goods (Siemieniuch et al., 1999), pharmaceutical goods (Narayana et al., 2014), video games (Broekhuizen et al., 2013), advertising (Bakhshi and McVittie, 2009) and music (Caves, 2000). Moreover, since market

(c) Sabet, Yazdani, De Leeuw. Published by Emerald Publishing Limited. This article is published under the Creative Commons Attribution (CC BY 3.0) licence. Anyone may reproduce, distribute, translate and create derivative works of this article (for both commercial and non-commercial purposes), subject to full attribution to the original publication and authors. The full terms of this licence may be seen at $\mathrm{http} / / /$ creativecommons.org/licences/by/3.0/legalcode 
IJLM

28,1

volatility is increasingly evident in global economies and life cycles in many industries are shortening (Christopher, 2000), FEI boundaries are expanding, which makes them an important category of industry to study.

However, there have been few studies defining the FEI or formulating transferable management knowledge and practices across different sectors of FEIs. Of those cross-industrial studies that do exist, a majority are market-focussed and relatively few are resource oriented. Cross-industrial market-focussed studies of FEIs include comparisons on customer satisfaction (Gilbert and Veloutsou, 2006), customer relationship (Wulf et al., 2001) and customer loyalty (Martensen et al., 2000). Examples of cross-industrial resource-focussed studies of FEIs are papers on competition mechanisms (Lieberman and Asaba, 2006), technological capabilities (Park et al., 2008), leadership style (Lok and Crawford, 2004) and strategic partnerships (Dodourova, 2009).

Since demand configurations are highly uncertain and fragmented in FEIs (Christopher et al., 2004), resource design and allocations in these industries are highly strategic and complex (Nachiappan and Jawahar, 2014). The higher the pace of change in an industry the larger is the impact of supply chain management (SCM) on the competitive advantage of the firms (Perrons and Platts, 2005). SCM must therefore be at the centre of strategic business reengineering efforts in FEIs (Arnold, 1999). Although there are numerous studies of SCM in FEIs within sectors they rarely go beyond sector boundaries to obtain cross-sectional SCM understanding.

The rapidly changing markets of FEIs point to an ever-increasing need for flexible and responsive supply chains (Gunasekaran et al., 2008; Christopher et al., 2004). Integration with suppliers is essential to meeting this need (Richey et al., 2009). Although supply chain integration ( $\mathrm{SCI}$ ) has received significant research focus in recent years (Wu and Barnes, 2011), with regard to FEIs it is an under-examined area of research.

This paper aims to develop a decision-making framework for SCI strategies and implementation mechanisms in FEIs. The next section explains how FEIs need agile and responsive supply systems and describes existing models and frameworks that could be used in FEIs. Section 3 further explains the importance of SCI as the main means of achieving agility and responsiveness for FEI supply chains. In an attempt to develop an SCM conceptual model and decision-making framework for FEI, Section 4 reviews the underlying drivers of SCI as well as the best implementation practices and mechanisms given the varying levels of supply uncertainty and varying levels of products/services importance to the core business of FEIs. The conceptual model and decision-making framework will be further elaborated by four mini cases, after which we conclude.

\section{FEIs and agile supply}

One of the earliest and major attempts to propose a supply selection model was by Kraljic (1983), who articulated that firms must adapt their purchase strategies to supply uncertainty. Kraljic (1983) suggested that SC strategies should be established on "the strategic importance of purchasing" and "the complexity of the supply network" (p. 110) in order to establish close collaboration with the suppliers. Later, Fisher's (1997) model asserted that demand structure differs by industry and that products/services are either functional or innovative. This model also categorised supply chains as "efficient" or "responsive" and identified which type fits best within different market structures. Fisher's model, therefore, is one of the earliest frameworks that can be employed for strategic supply chain selection in FEIs, as in these industries product life cycles tend to be short, demand is variable and product variety is often high. Employing this model for FEIs, the "market-responsive SC strategy" must be adopted "in order to minimize stock-outs, forced markdowns, and obsolete inventory" (Fisher, 1997, p. 108). However, this model does not provide the necessary level of detail on how responsive FEI suppliers must be, or how to operationalise this responsiveness.

Fisher (1997, p. 114) further advises that upon identifying an innovative product a company can manage uncertainty by "finding sources of new data that can serve as leading 
indicators, [...] cutting lead times and increasing the supply chain's flexibility". Such a market-responsive SC requires inventory buffers as well as up-to-date supply and demand data (Wong et al., 2006) to rapidly and efficiently respond to the changing market.

More recently, Lee (2002) proposed a framework to further develop the Fisher model. In an attempt to align SCM more closely with product and market needs, Lee made a distinction between efficient, risk-hedging, responsive or agile supply chains (ASCs) in relation to supply and demand uncertainty. Building on Fisher's work, which was based on "the matching of supply chain strategies to the right level of demand uncertainties of the product" (Lee, 2002, p. 106), Lee developed a new framework that included supply uncertainties. Applied to FEIs, the model suggests that an ASC would be the best fit, as their products/services can be categorised as innovative with higher demand uncertainty.

Although the concept of the ASC has become increasingly important for achieving a competitive edge in rapidly changing business environments (Wu and Barnes, 2014; Power et al., 2001), definitions of ASC and responsive supply chain (RCS) differ in literature. Fisher (1997) defines responsive processes as those that can "respond quickly to unpredictable demand in order to minimise stock-outs, forced markdowns and obsolete inventory". Christopher (2000), combines the idea of ASC and RSC and says, to become more responsive to the needs of a market requires more than speed. It also requires a high level of manoeuvrability that today has come to be termed agility.

Additionally, while some authors believe agile systems are an evolutionary extension of lean manufacturing systems (Gunasekaran et al., 2008) others assert that they are distinctly different (Naylor et al., 1999). Some, however, insist that these approaches can be combined to introduce "leagility" to systems (Naylor et al., 1999; Nachiappan and Jawahar, 2014). The definition of RSC by Gunasekaran et al. (2008) suggests a similarity between RCS and lean supply chain: "A network of firms that is capable of creating wealth to its stakeholders in a competitive environment by reacting quickly and cost effectively to changing market requirements". While Van Hoek et al. (2001) combine the concepts of agility, responsiveness and lean, stating: "Agility is all about customer responsiveness and mastering market turbulence and requires specific capabilities, on top of those that can be achieved using lean thinking".

Although ASC has been suggested for FEI, agility in SC still needs further clarification. From there, the challenge is to determine how FEIs can select appropriate resources strategies to achieve and implement this agility and, thereby, attain a sustainable competitive advantage.

\section{FEIs and integration}

As explained in the previous section, current supply chain frameworks lack the level of detail needed for an FEI SC. A one-size-fits-all strategy cannot be applied in SCM (Flynn et al., 2010) and FEI firms cannot manage supply chain design as other firms do in more stable industries. Langenberg et al. (2012, p. 501) argue that while the current focus is SCM mainly given to the products nature (either functional or innovative), there is also a need for "aligning the supply chain portfolio with the product portfolio". As discussed earlier, agility/ responsiveness is a critical requirement for FEIs; therefore, this section seeks to explain how it can be achieved and operationalised in FEI.

An ASC is a dynamic alliance of member companies responding to fast-changing markets (Luo et al., 2009) and it requires a high level of internal and external integration in order to provide the allied companies with the dynamicity they desire (Flynn et al., 2010). Although SCI is a relatively new research area (Flynn et al., 2010), it is now widely considered to be core to successful SCM (Richey et al., 2009, p. 827), particularly within FEIs (Luo et al., 2009). There are various definitions of SCI (van der Vaart and van Donk, 2008). In this paper, however, we employ the definition by Chen et al. (2009), as they link integration with agility, defining SCI as integration of information systems or physical 
IJLM

28,1

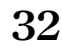

processes to create a more agile and efficient supply. The implication is that SCM can be studied as a range of relationships, classified on a spectrum from distant to very close (Harland, 1996). For example, Ellram (1991) presents this spectrum with a transactional contract on one end and vertical integration (VI) acquisition on the other.

While integration envisages a long-term relationship between purchasers and suppliers, the requirements of dynamic markets in FEIs may prompt more frequent re-evaluation of relationships by FEI managers (Luo et al., 2009). Identifying the best integration strategy for FEIs therefore requires a wide understanding of trade-offs and strategic alternatives (Moses and Ahlstrom, 2008).

\section{Conceptual model and SC decision framework for FEI}

Although market structure for FEIs is often volatile, they require a stable SC, as Harland et al. (2003) argue that the more stable the supply network, the more responsive it will be. To keep up with market uncertainties, FEI firms must be able to manage effectively the variations and uncertainties in their supply systems. Supply chain uncertainty has been widely defined and discussed in the literature (Trkman and McCormack, 2009). For this study, we follow van der Vorst and Beulens (2002), who conceptualise SC uncertainty as decision-making situations in the supply chain in which decision makers are unable to collect enough information/understanding about the supply chain and its environment, or unable to predict the impact of possible control actions on supply chain behaviour. To minimise supply risk and uncertainty it is important for FEI firms to choose the right integration strategy (Trkman and McCormack, 2009) as well as adequate information- and knowledge-sharing systems to implement selected integration strategies (Li, 2007), hence highlighting the need for a steering SC model and decision framework in this industry.

Although the importance of SCI in agile systems has been widely acknowledged (Stavrulaki and Davis, 2010) the best level of integration and how to achieve it are topics that have not been fully explored in the SCM literature (Tsanos et al., 2014). While it is believed that a higher SCI is generally more desirable (Giménez and Ventura, 2005), high levels of integration is expensive (Bensaou, 1999), difficult to achieve and maintain (Arshinder and Deshmukh 2008; Lafontaine and Slade, 2007), sometimes risky (Bagchi et al., 2005; Guan and Rehme, 2012) and not necessarily the best practice in all situations (Power, 2005; Bagchi and Skjoett-Larsen, 2002; Bask and Juga, 2001; de Leeuw and Fransoo, 2009). Therefore, integration with suppliers is a trade-off that needs to be strategized (Chopra and Sodhi, 2004; Bensaou, 1999). To achieve the right level of integration three strategies can be utilised - information integration, process integration or VI (Gunasekaran et al., 2008; Fabbe-Costes and Jahre, 2008) - all of which we have employed in designing the SCI conceptual model for this study, illustrated in Figure 1(a).

Determining an appropriate level of integration with suppliers depends upon how closely a business chooses to work with a supplier, subject to supply stability (de Leeuw and Fransoo, 2009), as well as the types of products and the production systems (Li, 2007). Our model (Figure 1(a)) explains how to strategize the required level of integration, given an assessment of the level of uncertainty in supply and the importance of the supplied product/ service to the core business of the FEI firms.

The arrows in Figure 1(a) indicate the underlying drivers for suggested integration strategies and show that, by deploying higher integration levels, FEI firms would develop core competencies in their markets and a hedge against supply uncertainty/risk. To explain the horizontal arrow, we employ the concepts "resource-based view", "competitive advantage" (Rumelt, 1984; Barney, 1991, 2012) and core competency (Prahalad and Hamel, 1990). Despite some differences between these ideas, they all convey that superior performance of firms can be achieved through their ability to accumulate resources and capabilities that are rare, valuable and difficult to imitate, which in turn enable them to create and maintain 


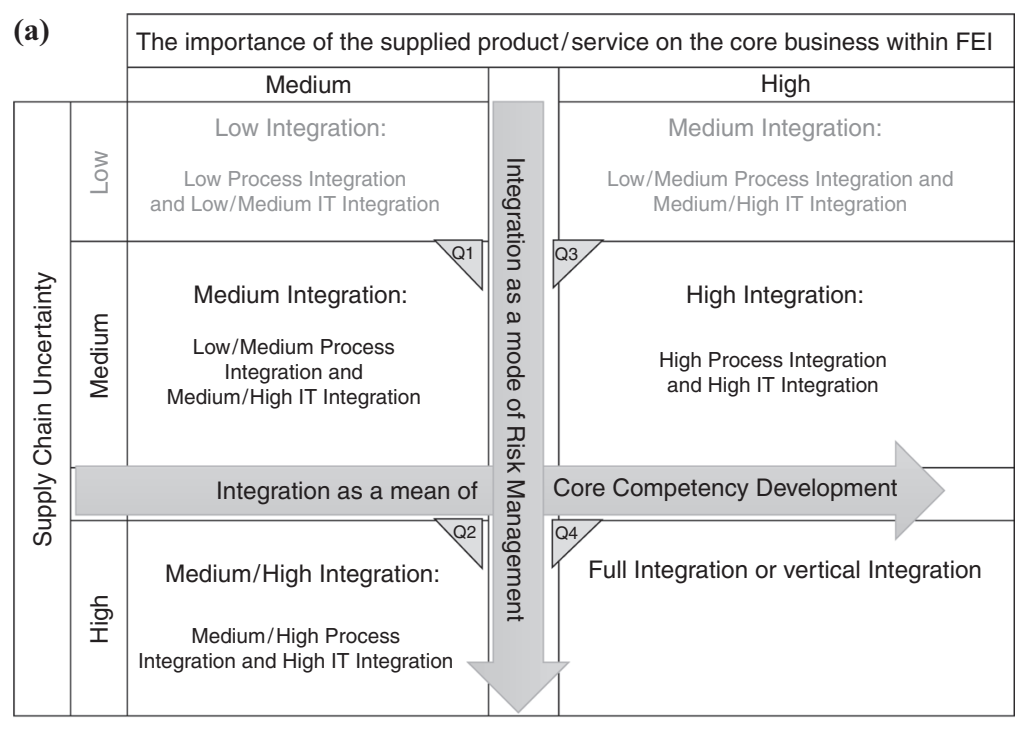

(b) The importance of the supplied product/service on the core business within FEI

\begin{tabular}{|c|c|c|c|}
\hline & Medium & \multirow{2}{*}{$\begin{array}{l}\text { High } \\
\text { Conventional purchase and logistics } \\
\text { management with higher information and } \\
\text { know-how sharing with key suppliers (joint } \\
\text { product and technology development) }\end{array}$} \\
\hline & 3 & $\begin{array}{l}\text { Conventional purchase and logistics } \\
\text { management }\end{array}$ & \\
\hline \multirow{2}{*}{ 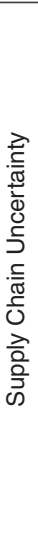 } & 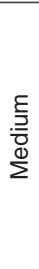 & $\begin{array}{l}\text { - Flexible and risk-sharing supply } \\
\text { contracts } \\
\text { - Quantity flexibility contracts } \\
\text { Vendor managed inventory-Make } \\
\text { to availability-Make to order- } \\
\text { Collaborative planning, forecasting } \\
\text { and replenishment }\end{array}$ & $\begin{array}{l}\text { - Partnership } \\
\text { - Virtual Enterprises } \\
\text { - Factories-within-a-factory }\end{array}$ \\
\hline & 돔 & $\begin{array}{l}\text { - IT integration from the point-of-use } \\
\text { to upstream supply (create a virtual } \\
\text { supply chain); } \\
\text { - Lead time based Supplier selection, } \\
\text { order decoupling point, or } \\
\text { Postponement } \\
\text { - TOC SCM: Aggregated buffers; or } \\
\text { capacity-based supply chain } \\
\text { contracts (capacity buffering) }\end{array}$ & $\begin{array}{l}\text { - Strategic Partnership } \\
\text { - Joint Ventures } \\
\text { - Direct investment }\end{array}$ \\
\hline
\end{tabular}

Notes: (a) Conceptual model: supply chain integration strategies and drivers;

(b) decision framework: supply chain integration implementation mechanisms

Figure 1.

Conceptual model and decision-making framework for supply chain integration strategies and implementation methods in fast evolving industries

competitive advantages and competencies (Hinterhuber, 2013). Many authors have argued that firms in evolving markets need agility as a competitive advantage (Yusuf et al., 1999; Ramsay, 2001; Sharifi and Zhang, 2001; Li et al., 2008; Lai et al., 2012). As discussed before, integration with supply systems enhances agility and responsiveness in FEI firms and therefore develops sustainable competitive advantages (Richey et al., 2009). Figure 1(a) 
IJLM

28,1

illustrates that the more important the supplied products/services are to the core business, the more firms must integrate with their suppliers to secure their value creation processes and to protect their core business (Giménez and Ventura, 2003).

On the other hand, when risk and uncertainty in supply is high, firms must aim for alignment, adaptability and agility in their SC (Lee, 2004). To this end, the vertical arrow in Figure 1(a) indicates that FEI firms need more integrated systems to hedge against variations and uncertainties in supply (Wu et al., 2006; Li et al., 2006; Mellat-Parast and Spillan, 2014; Gligor and Holcomb, 2014). IT integration with suppliers helps firms and their suppliers share information about the market and supply, in order to responsively manage their processes (Kim, 2006; Chen et al., 2007; Closs and Savitskie, 2003) and hedge against risk (Ponomarov and Holcomb, 2009). IT integration also reduces the bullwhip effect, which commonly affects upstream suppliers in fast-changing markets (Lee et al., 2004).

While Figure 1(a) reflects an SCI conceptual model for FEI to strategize integration levels, Figure 1(b) offers additional detail and a decision-making framework for the implementation mechanisms to operationalise the integration solutions. Bensaou (1999) explains that a successful SC decision model must not only match the optimal SC relationship with the supplied products/services, but also direct its users to the best implementation policies for each type of relationship. A sound implementation policy can also provide FEI firms with considerable competitive advantage (Lowson, 2001).

If supply is relatively stable in a FEI firm existing decision models, as discussed in previous sections, are still operational. In such a situation (low-supply uncertainty), process integration is not essential (Power, 2005; Bagchi and Skjoett-Larsen, 2002). IT integration, however, can drive a general responsiveness of the firm (Williams et al., 2013). When the importance of the supplied product/service to the FEI firm becomes greater, the IT centralisation and information sharing plays a more important role in supply management of the firms (Qrunfleh and Tarafdar, 2015) though integration levels do not need to be high. The main focus of our model is on medium-to-high supply uncertainty and product importance since these require higher levels of integration. Therefore, the remainder of this section explains the SCI implementation choices illustrated in quadrants 1 to 4 in Figure 1(b). Each quadrant can be distinguished by the criticality of the supplied product/service to the core business and by SC uncertainty. Below we discuss implementation choices, followed by a mini-case study for each quadrant.

\section{Quadrant 1: medium importance of supplied product/service and medium SC uncertainty and risk}

As discussed before, when supply uncertainty and risk are not significant, and neither is the importance of the supplied product/service to the core business of the firms, the integration trade-off moves in the direction of less centralisation; therefore, low-to-medium overall integration tends to be sufficient. However, since life cycles are generally very short in FEI firms (Christopher, 2000) they cannot afford to carry significant levels of stock to deal with market or supply fluctuations (Milner and Rosenblatt, 2002). Even when uncertainty is not significant they need to be agile and responsive.

The viable solution is flexible supply contracts, which help FEI firms maintain the required level of agility and responsiveness without much integration (Marquez and Blanchar, 2004). The baseline requirements to implement flexible SC contracts are culture, trust and structure for sharing information (Sabath et al., 2001; Bagchi et al., 2005), low-cost and flexible electronic data interchange (Fürst and Schmidt, 2001) and co-managed inventory (CMI) (Christopher et al., 2004). In addition, Arshinder and Deshmukh (2008) classified SC contract integrity, IT and information sharing and joint decision making as required coordination mechanisms. These conditions imply a need for medium/low-process integration and higher IT integrity with suppliers (Harris et al., 1998). 
Medium coordination mechanisms (flexible SC contracts) are designed to facilitate the flow of products and information in the SC and comprise various implementation techniques, such as vendor manager inventory (VMI), make-to-availability, make-to-order, quick response, collaborative planning, forecasting and replenishment and effective consumer response (Wong et al., 2009; Tang, 2006). Most of these implementation methods are based on the concept of quantity flexible contracts (QFC) (Tsay and Lovejoy, 1999). Although QFC occasionally causes relatively higher non-discounted supply prices (Marquez and Blanchar, 2004), it leads to a pull contract which clears the risk of unsold inventory and, in turn, reduces the final cost and supply risk (Cachon, 2004). Among QFC implementation methods, VMI has received significant attention in the literature and in practice (Buzzell and Ortmeyer, 1995; Waller et al., 1999; Disney and Towill, 2003). VMI is shown to be significantly better than traditional fixed-term contracts at responding to uncertain and changing markets (Nachiappan and Jawahar, 2008), recovering from major fluctuations and dampening bullwhip effects in downstream supply (Disney and Towill, 2003).

Case evidence. This case study is adapted from Partnerships in the Supply Chain: Introducing Co-managed Inventory at Guinness $G B$ (Peck, 1998). It details the successful implementation of flexible SC contracts with a focus on a type of VMI, called CMI (Blatherwick, 1998), which requires collaboration among SC partners. The beer industry for Guinness ${ }^{\circledR}$ is split into two sectors, the on-trade and off-trade markets. To on-trade markets Guinness ${ }^{\circledR}$ tends to be a stable supplier as demand is generally predictable and relatively stable; however, to supermarkets Guinness ${ }^{\circledR}$ was previously an unstable supplier due to their slow response to changing demand orders. Peck (1998) explains that order fluctuations from supermarkets are inevitable as customers are not generally loyal to a certain supermarket. At the same time, constant price promotions and competition from other beer brands imply a need for a stable and responsive supply.

To address the need for a stable and responsive SC with it supermarket customers, Guinness ${ }^{\circledR}$ began implementing a CMI strategy, which not only solved its supermarket problem but enabled it to extend its off-trade market, thanks to a greater ability to share inventory information and thus forecast demand (Peck, 1998). Sharing this information was a key enabler to build relationships with customers.

Quadrant 2: medium importance of supplied product/service and high-SC uncertainty and risk When uncertainty and risk in supply are significant, risk-hedging strategies are used to maintain the required level of agility in supply. These strategies require a high level of information integration (Wu et al., 2006; Li et al., 2006). In FEIs, downstream demand must be clearly visible; moreover, demand information needs to be captured as far down the chain as possible and shared with upstream suppliers (Christopher, 2000). Identified enablers of making demand visible and measurable are strategic planning, virtual enterprise (VE) and knowledge and IT management (Gunasekaran et al., 2008). Additionally, Arshinder and Deshmukh (2008) identified three coordination policies to make downstream demand more visible and measurable to upstream supply chain, through SC contracts, IT and information sharing and joint decision making. When a significant level of coordination is required, process misalignments between firms and their suppliers must be resolved (Piplani and $\mathrm{Fu}, 2005)$. Therefore, such situations call for high-IT integration and medium process integration (Figure 1(a)).

To implement this strategy, Fisher (1997) directs companies to seek sources of new and accurate data, share information from point-of-sale throughout the supply chain, extend the use of common components and employ postponement techniques to manage SC uncertainty and risk (Fisher, 1997). The use of information technology to share data between buyers and suppliers creates a virtual supply chain, which is more information based than 
IJLM

28,1

inventory based (Christopher, 2000). VEs are characterised by the following strategic objectives: maximising flexibility and adaptability to environmental changes (Gunasekaran et al., 2008); and minimising the bullwhip effect in upstream supply by sharing information and strategic decisions with the supply chain (Lee, 2002).

Fisher (1997) also suggests that responsive systems seek to cut SC lead times in order to improve the level of responsiveness in their supply. This can be achieved by selecting suppliers in geographically close distances or faster transportation modes to cut the delivery times (Ferdows et al., 2004; Stratton and Warburton, 2003) as well as through inventory centralisation and aggregation (Tallon, 1993; Van Donk, 2001; Olhager, 2003). The implementation of an SC decoupling policy will also help to manage the impact of demand variation in upstream supply by increasing the possibility of postponement of activities (Hoekstra et al., 1991). Postponement, however, "requires careful crossfunctional integration involving modular design to ensure the market order winners and qualifiers are satisfied" (Stratton and Warburton, 2003, p. 189).

However, when postponement is not operational, holding higher inventories seems to be the only option to cope with the SC instabilities (Baker, 2007). To overcome inventory vs agility conflicts, the theory of constraints as articulated by Goldratt (1990) would suggest aggregated buffers (Jammernegg and Reiner, 2007; Rahman, 2002) rather than enterprise resource planning (ERP) and other forecast-based scheduling systems, as such conventional inventory management practices are not suitable for fast-changing environments (Gupta, 2003; Yuan et al., 2003; Umble et al., 2001). Aggregated buffers can be implemented through buffering inventory, time and capacity (Stratton and Warburton, 2003). Inventory buffering can be used in manufacturing and retail industries where physical goods are traded, (Jammernegg and Reiner, 2007), while time buffering can be employed in the service industries (Umble and Umble, 2006; Stratton and Knight, 2010) and within project-based activities (Hu et al., 2014; Kuo et al., 2009; Barber et al., 1999). Capacity buffering (reserving excess capacity) can be implemented in cases where uncertainty and variation in market and supply are significant and forecast systems are inherently undependable, and where, therefore, inventory buffering is not a viable solution (Hill et al., 2012). Capacity buffers, which can be secured by a flexible capacity supply contract, can provide FEI firms with a high level of manufacturing/service agility and responsiveness (Hill et al., 2012).

Case evidence. This case study, titled "Fashion unleashed: the agile fashion supply chain", is aimed at providing information on industry dynamics and its effects on supply chains in the fashion industry (Harrington and Smith, 2013). High SC uncertainty and complexity are evident in this industry, requiring "appropriate speed, flexibility, responsiveness and control" (p. 2). The authors expand upon a number of common strategies to build an "adaptive fashion supply chain" designed to deal with constraints in capacity and inventory, as well as to manage product life cycles of fast fashion items. This approach fits into the strategy selection scenario of capacity-based SC contracts and buffering, as suggested in our framework.

For example, the authors explain that the case company uses an efficient $\mathrm{SC}$ model for staple fashion items by which it is able to set a level of capacity because demand from all markets is pooled together within a centralised inventory, which is then managed by a push process. For those goods where design does not change seasonally, it is possible to work on longer term contracts with wholesalers who can "provide large quantities purchased in advance" (Harrington and Smith, 2013, p. 12). However, for goods that are considered fast fashion, SCs look for commonalities in product lines, which can be grouped together, thus creating more opportunities for long-term contracts (Harrington and Smith, 2013). For example, purchasing a high volume of material every month and making final design at the very last stage in production in order to follow the latest fashion in the market. The authors explain that this approach fits with a postponement strategy, which "helps 
companies quickly ramp up in fast-growing markets while at the same time optimizing production" (p. 14) in order to give customers the most up-to-date fashion trends.

In summary, this case shows how a fast fashion company with significant supply chain uncertainty can use long-term capacity-based contracts, combined with postponement and high-information sharing (from the point-of-sale) to improve supply stability while offering innovative and fashionable items. This strategy enables the company "to serve markets around the world with a supply chain that is resilient enough to withstand shocks, agile enough to respond quickly [...] flexible enough to customise products and efficient enough to protect margins" (Harrington and Smith, 2013, p. 18).

Quadrant 3: high importance of supplied product/service and medium SC uncertainty and risk As the importance of the supplied products/services becomes high, firms attempt to protect their know-how as well as their supply channels and distribution networks in order to secure their competencies (Prahalad and Hamel, 1990). Partnerships and alliances can help firms improve flexibility and responsiveness (Gunasekaran et al., 2008). However, these require a high level of integration and coordination with the few suppliers with which FEI firms can develop further competitive advantages or protect their core competencies (Gunasekaran et al., 2008). However, competencies are not always attached to individual companies; at times, they are a function of the way companies interact with their suppliers and partners (Freytag and Kirk, 2003). Shared information and interaction between supply chain partners can be fully utilised only through process integration, which includes: collaborative working between buyers and suppliers, joint product development, common systems, merging processes, shared operations management, joint strategy determination, buyer-supplier cross-functional teams and open-book accounting (Christopher, 2000). Quadrant 3 is thus characterised by high process and IT integration between FEI firms and their suppliers, based on core competency advancement and partnership development.

VE is a deeper level of partnership and a solution to situations in which the importance of supply becomes highly critical (Wang et al., 2006). Gunasekaran et al. (2008) define VE as "developing partnerships based on core competencies for achieving agility in a supply chain environment". They also identify a number of related "strategies, techniques and technologies": "networks of suppliers, core competencies, strategic alliances, education and training, communication, IT such as ERP, communication for global supply chain, managing processes, partnership development, streamlined logistics network, empowered teams, legal protection, virtual logistics, virtual manufacturing, computer and communication technologies, organizational structure and relationship [...]".

The success of VE projects depends on how partners cooperate as a single unit. VE projects must be delicately strategized before implementation and can be hindered by lack of trust, lack of IT integration mechanisms, organisational cultural differences and fear of losing competitive advantage (Martinez et al., 2001; Handfield and Bechtel, 2002; Kemppainen and Vepsäläinen, 2003). Such conditions highlight the need for an SC collaboration framework, as well as performance metrics for measurement and monitoring, in order to help firms select and implement appropriate collaboration strategies and secure the best partnerships to achieve them (Ramanathan et al., 2011).

Factories-within-a-factory is an example of the successful implementation of a close partnership with suppliers to increase responsiveness and improve the competitive advantage of firms (Miltenburg, 2008).

Case evidence. The third case study is entitled "Collaborative innovation in the global semiconductor industry" (Kapoor, 2011). Reflective of the scenario of high SC uncertainty and very high importance of the supplied product or service, this study finds that 
IJLM

28,1

semiconductor companies "are subjected to high technological complexity, short product life cycles and hard-to-change cost structures" (Kapoor, 2011, p. 6).

The solution, offered by the case, is to form a partnership. The authors describe this as "pursuing collaborative innovation models in which value is created not only within the company, but also at the collaborative interface between the company and its diverse set of partners" (Kapoor, 2011, p. 3). The partnership is created with different members of the SC, including suppliers of complementary products, who help the semiconductor company to create innovative value for the end customer.

The PC and semiconductor markets were once vertically integrated. Eventually, however, the supply chains reverted to being more specialized (Fine, 2000). Whilst developing their core skills and capabilities, a semiconductor company can work closely with others, who provide input to the final product where innovation is critical and its success has a high impact on the core business.

After conducting two years of research in the "2010 Wharton-GSA Semiconductor Ecosystem Survey", Kapoor (2011) found that, in addition to external partners such as original equipment manufacturers and complementary product providers, successful innovation relies upon partnerships with internal groups. These groups can collaborate on product innovations "which link the company's internal activities with those of its upstream and downstream suppliers" (Kapoor, 2011, p. 3).

Working in this way appears to be critical to the semiconductor industry; whilst SC uncertainty remains, close-natured relationships play an important role "in enhancing the semiconductor company's competitive position” (Kapoor, 2011, p. 6).

Quadrant 4: high importance of supplied product/service and high SC uncertainty and risk The end of the spectrum happens when supplied products/services are of significant importance to the survival of FEI firms and SC uncertainty is too high and too risky to be solely and externally handled by suppliers. In this situation, FEI firms often pursue full integration strategies aimed at securing the highest controllability of resources, so as to manage uncertainty and protect their businesses (Frohlich and Westbrook, 2001). This fully integrated policy can be operationalised through strategic partnerships, joint ventures, direct investments, or at the highest level, VI (Ellram, 1991; Li, 2007). Early definitions of VI employing transaction cost theories date from 1960s to 1980s (McDonald, 1985; Balakrishnan and Wernerfelt, 1986). However, contemporary interest in VI seems to be driven by more than cost minimisation (Guan and Rehme, 2012; Frohlich and Westbrook, 2001).

Several motivations have been identified for adopting full integration policies (Guan and Rehme, 2012), including: overcoming technical complexity; differentiation capability to advance competitive advantage of the firms; securing higher margins; strategic partnering with key suppliers to keep them away from competitors and protect core competencies; developing customer demand integrated solutions; creating synergies in the chain; and learning from key suppliers. Trust, infrastructure, organisational culture, technological differences and management styles have been identified as highly influential factors (Rossi et al., 2013; Martinez et al., 2001; Handfield and Bechtel, 2002; Kemppainen and Vepsäläinen, 2003).

Case evidence. This case focusses on the article in Business Time entitled "How Apple Made 'Vertical Integration' Hot Again - Too Hot, Maybe” (Knowledge@Wharton, 2012). The hightech electronics industry, where innovations are a common occurrence in the marketplace, is characterised by very high importance of the product or service on the core business as well as very high SC uncertainty; this suggests a high tendency towards VI (Figure 1).

Knowledge@Wharton (2012, p. 1) reports that many big technology companies are vertically integrating activities with the result that "one company controls the end product 
as well as its component parts" (i.e. the integration of hardware and software). This fully integrated policy, which started with Apple, is being copied by many other large technology corporations, such as Motorola, Amazon and Oracle, who are trying to maintain growth and competitiveness in this demanding and fast-paced industry (Knowledge@Wharton, 2012). It appears that activities are easier to manage when a company has full control over the closely linked and key complementary products and services that connect to the core business - for example, the operating systems, service platforms and key hardware components for mobile phones.

For this VI strategy to be successful, Knowledge@Wharton (2012) suggest that business units needs to be fully connected and integrated, because if the products or services are not related it is difficult to centralise the work and coordinate activities. To vertically integrate, firms need to focus on their core skills and how these can be integrated to work across functions in order to remain competitive and innovative. This is critical to the fast-paced nature of the technology industry.

It should be possible for all business units to collaborate more closely given a highest level of information sharing as supply and demand change. On the other hand, the innovation level may be at risk if a company has too many activities to manage; thus, outsourcing is still a viable strategy for activities/products that are not core to the business (Knowledge@Wharton, 2012).

\section{Conclusion}

SCI has been a matter of debate in the SCM domain for decades. However, as global markets change and new industries emerge, current SCM frameworks are not as effective in helping emerging and evolving industries to formulate their resource strategies, or to steer them in implementing those policies.

The FEI, which is defined in this study, accounts for a large proportion of growing and often high added-value industries, such as electronics and telecommunications, semiconductors, fast moving consumer goods, pharmaceutical goods, video games, advertisement and music industry. FEIs are identified by high levels of innovation and differentiation, high-product/service variety and low-product/service life or replenishment cycle, and increasingly sophisticated customers. Therefore, a constant need is evident in such industries to align supply requirements with the ever-changing customer demands. FEI firms require an ability to be more than just responsive to market variations. They must also be capable of proactively hedging against supply risks and constantly developing core competencies in order to survive and grow in their fast evolving markets. The existing SC frameworks in the literature lack the precision and details required in this domain for steering practitioners and scholars. The SCM conceptual model and strategic decisionmaking framework designed by this paper (Figure 1) can assist decision-makers in FEIs to optimise their SC integration strategies and deploy those strategies by choosing the best implementation policies, in order to sustain their competitiveness in risky supply conditions.

\section{Limitation and further studies}

- Since this framework is designed at a strategic level, risk and uncertainty are not fully differentiated. This might be argued as a limitation to the study, as many authors believe risk and uncertainty are entirely different (Alvarez and Barney, 2005; McKelvie et al., 2011).

- Implementation methods in the framework (Figure 1(b)) are not extensive and further studies might offer an inclusive list; moreover, further case studies and empirical research could deepen findings. 
- Although the FEI has been defined in this study, it still in need of further research to detail its industry boundaries. Besides, transferable and cross-industrial management knowledge within FEI firms also needs further focus to explore what resource-based management approaches can be learnt and transferred across the sectors within FEI firms. This is part of the ongoing research of the authors of this paper.

\section{References}

Alvarez, S. and Barney, J.B. (2005), "How do entrepreneurs organize firms under conditions of uncertainty?”, Journal of Management, Vol. 31 No. 5, pp. 776-793.

Arnold, U. (1999), "Organization of global sourcing: ways towards an optimal degree of centralization", European Journal of Purchasing \& Supply Management, Vol. 5 No. 1999, pp. 167-174.

Arshinder, K.A. and Deshmukh, S.G. (2008), "Supply chain coordination: perspectives, empirical studies and research directions", International Journal of Production Economics, Vol. 115 No. 2, pp. 316-335.

Bagchi, P.K. and Skjoett-Larsen, T. (2002), "Organizational integration in supply chains: a contingency approach”, Global Journal of Flexible Systems Management, Vol. 3 No. 1, pp. 1-10.

Bagchi, P.K., Ha, B.C., Skjoett-Larsen, T. and Soerensen, L.B. (2005), "Supply chain integration: a European survey", The International Journal of Logistics Management, Vol. 16 No. 2, pp. 275-294.

Baker, P. (2007), "An exploratory framework of the role of inventory and warehousing in international supply chains”, International Journal of Logistics Management, Vol. 18 No. 1, pp. 64-80.

Bakhshi, H. and McVittie, E. (2009), "Creative supply-chain linkages and innovation: do the creative industries stimulate business innovation in the wider economy?", Innovation: Management, Policy \& Practice, Vol. 11 No. 2, pp. 169-189.

Balakrishnan, S. and Wernerfelt, B. (1986), "Technical change, competition and vertical integration", Strategic Management Journal, Vol. 7 No. 4, pp. 347-359.

Barber, P., Tomkins, C. and Graves, A. (1999), "Decentralised site management - a case study", International Journal of Project Management, Vol. 17 No. 2, pp. 113-120.

Barney, J.B. (1991), "Firm resources and sustained competitive advantage", Journal of Management, Vol. 17 No. 1, pp. 99-120.

Barney, J.B. (2012), "Purchasing, supply chain management and sustained competitive advantage: the relevance of resource-based theory”, Journal of Supply Chain Management, Vol. 48 No. 2, pp. 3-6.

Bask, A.H. and Juga, J. (2001), "Semi-integrated supply chains: towards the new era of supply chain management", International Journal of Logistics: Research Applications, Vol. 4 No. 2, pp. 137-152.

Bensaou, M. (1999), "Portfolios of buyer-supplier relationships", Sloan Management Review, Vol. 40 No. 4, pp. 35-44.

Bilgen, B. and Günther, H.O. (2010), "Integrated production and distribution planning in the fast moving consumer goods industry: a block planning application”, OR Spectrum, Vol. 32 No. 4, pp. 927-955.

Blatherwick, A. (1998), "Vendor-managed inventory: fashion fad or important supply chain strategy?", Supply Chain Management: An International Journal, Vol. 3 No. 1, pp. 10-11.

Broekhuizen, T.L.J., Lampel, J. and Rietveld, J. (2013), "New horizons or a strategic mirage? Artist-leddistribution versus alliance strategy in the video game industry", Research Policy, Vol. 42 No. 2013, pp. 954-964.

Brown, A.O., Lee, H.A. and Petrakian, R. (2000), "Xilinx improves its semiconductor supply chain using product and process postponement", Interfaces, Vol. 30 No. 4, pp. 65-80. 
Buzzell, R.D. and Ortmeyer, G. (1995), "Channel partnerships streamline distribution", Sloan Management Review, Vol. 36 No. 2, pp. 85-96.

Cachon, G.P. (2004), "The allocation of inventory risk in a supply chain: push, pull, and advancepurchase discount contracts", Management Science, Vol. 50 No. 2, pp. 222-238.

Caves, R.E. (2000), Creative Industries, Contracts Between Art and Commerce, Harvard University Press, Cambridge, MA, available at: www.loc.gov/crb/proceedings/2006-3/riaa-ex-o-148-dpamended.pdf (accessed 18 March 2014).

Chen, D., Mattioda, D.D. and Daugherty, P.J. (2007), "Firm-wide integration and firm performance", The International Journal of Logistics Management, Vol. 18 No. 1, pp. 5-21.

Chen, H., Daugherty, P.J. and Landry, T.D. (2009), "Supply chain process integration: a theoretical framework", Journal of Business Logistics, Vol. 30 No. 2, pp. 27-46.

Chopra, S. and Sodhi, M.S. (2004), "Managing risk to avoid supply-chain breakdown", MIT Sloan Management Review, Vol. 46 No. 1, pp. 53-61.

Christopher, M. (2000), "The agile supply chain: competing in volatile markets", Industrial Marketing Management, Vol. 29 No. 1, pp. 37-44.

Christopher, M., Lowson, R. and Peck, H. (2004), "Creating agile supply chains in the fashion industry", International Journal of Retail and Distribution Management, Vol. 32 No. 8, pp. 367-376.

Closs, D.J. and Savitskie, K. (2003), "Internal and external logistics information technology integration", International Journal of Logistics Management, Vol. 14 No. 1, pp. 63-76.

de Leeuw, S. and Fransoo, J. (2009), "Drivers of close supply chain collaboration: one size fits all?", International Journal of Operations \& Production Management, Vol. 29 No. 7, pp. 720-739.

Disney, S.M. and Towill, D.R. (2003), "The effect of vendor managed inventory (VMI) dynamics on the bullwhip effect in supply chains", International Journal of Production Economics, Vol. 85 No. 2, pp. 199-215.

Dodourova, M. (2009), "Alliances as strategic tools: a cross-industry study of partnership planning, formation and success”, Management Decision, Vol. 47 No. 5, pp. 831-844.

Ellram, L.M. (1991), "Supply chain management: the industrial organisation perspective", International Journal of Physical Distribution and Logistics Management, Vol. 21 No. 1, pp. 13-22.

Fabbe-Costes, N. and Jahre, M. (2008), "Supply chain integration and performance: a review of the evidence", The International Journal of Logistics Management, Vol. 19 No. 2, pp. 130-154.

Ferdows, K., Lewis, M.A. and Machuca, J.A. (2004), "Rapid-fire fulfilment", Harvard Business Review, Vol. 82 No. 1, pp. 104-117.

Fine, C.H. (2000), "Clockspeed-based strategies for supply chain design 1", Production and Operations Management, Vol. 9 No. 3, pp. 213-221.

Fisher, M.L. (1997), "What is the right supply chain for your product?", Harvard Business Review, Vol. 75 No. 2, pp. 105-116.

Flynn, B.B., Huo, B. and Zhao, X. (2010), "The impact of supply chain integration on performance: a contingency and configuration approach", Journal of Operations Management, Vol. 28 No. 1, pp. 58-71.

Freytag, P.V. and Kirk, L. (2003), "Continuous strategic sourcing”, Journal of Purchasing \& Supply Management, Vol. 9 No. 2003, pp. 135-150.

Frohlich, M.T. and Westbrook, R. (2001), "Arcs of integration: an international study of supply chain strategies”, Journal of Operations Management, Vol. 19 No. 2, pp. 185-200.

Fürst, K. and Schmidt, T. (2001), "Turbulent markets need flexible supply chain communication", Production Planning \& Control, Vol. 12 No. 5, pp. 525-533.

Gilbert, G.R. and Veloutsou, C. (2006), "A cross-industry comparison of customer satisfaction", Journal of Services Marketing, Vol. 20 No. 5, pp. 298-308.

Giménez, C. and Ventura, E. (2003), "Supply chain management as a competitive advantage in the spanish grocery sector”, International Journal of Logistics Management, Vol. 14 No. 1, pp. 77-88. 
Giménez, C. and Ventura, E. (2005), "Logistics-production, logistics-marketing and external integration - their impact on performance", International Journal of Operations and Production Management, Vol. 25 No. 1, pp. 20-38.

Gligor, D.M. and Holcomb, M. (2014), "The road to supply chain agility: an RBV perspective on the role of logistics capabilities", The International Journal of Logistics Management, Vol. 25 No. 1, pp. 160 -179.

Goldratt, E.M. (1990), Theory of Constraints, North River Press, Croton-on-Hudson, NY.

Guan, W. and Rehme, J. (2012), "Vertical integration in supply chains: driving forces and consequences for a manufacturer's downstream integration”, Supply Chain Management: An International Journal, Vol. 17 No. 2, pp. 187-201.

Gunasekaran, A., Lai, K. and Edwin Cheng, T.C. (2008), "Responsive supply chain: a competitive strategy in a networked economy", Omega, Vol. 36 No. 2008, pp. 549-564.

Gupta, M. (2003), "Constraints management - recent advances and practices”, International Journal of Production Research, Vol. 41 No. 4, pp. 647-659.

Handfield, R.B. and Bechtel, C. (2002), "The role of trust and relationship structure in improving supply chain responsiveness", Industrial Marketing Management, Vol. 31 No. 4, pp. 367-382.

Harland, C., Brenchley, R. and Walker, H. (2003), "Risk in supply networks", Journal of Purchasing \& Supply Management, Vol. 9 No. 2003, pp. 51-62.

Harland, C.M. (1996), "Supply chain management: relationships, chains and networks", British Journal of Management, Vol. 7 No. S1, pp. 63-80.

Harrington, L. and Smith, R.H. (2013), "Fashion unleashed: the agile fashion supply chain”, White Paper, DHL Supply Chain.

Harris, A., Giunipero, L.C. and Hult, G.T.M. (1998), "Impact of organizational and contract flexibility on outsourcing contracts", Industrial Marketing Management, Vol. 27 No. 5, pp. 373-384.

Hill, A., Doran, D. and Stratton, R. (2012), "How should you stabilise your supply chains?”, International Journal of Production Economics, Vol. 135 No. 2, pp. 870-881.

Hinterhuber, A. (2013), "Can competitive advantage be predicted? Towards a predictive definition of competitive advantage in the resource-based view of the firm", Management Decision, Vol. 51 No. 4, pp. 795-812.

Hoekstra, S., Romme, J. and Argelo, S.M. (1991), Integrated Logistics Structures: Developing CustomerOriented Goods Flow, McGraw-Hill, London.

Hu, X., Cui, N. and Demeulemeester, E. (2014), "Effective expediting to improve project due date and cost performance through buffer management", International Journal of Production Research, Vol. 53 No. 5, pp. 1460-1471.

Humphrey, J. and Schmitz, H. (2002), "How does insertion in global value chains affect upgrading in industrial clusters?”, Regional Studies, Vol. 36 No. 9, pp. 1017-1027.

Jammernegg, W. and Reiner, G. (2007), "Performance improvement of supply chain processes by coordinated inventory and capacity management", International Journal of Production Economics, Vol. 108 No. 1, pp. 183-190.

Kapoor, R. (2011), "Collaborative innovation in the global semiconductor industry", A report on the findings from the 2010 Wharton-GSA Semiconductor Ecosystem Survey, Global Semiconductor Alliance.

Kemppainen, K. and Vepsäläinen, A.P.J. (2003), "Trends in industrial supply chains and networks", International Journal of Physical Distribution \& Logistics Management, Vol. 33 No. 8, pp. 701-719.

Kim, S.W. (2006), "Effects of supply chain management practices, integration and competition capability on performance", Supply Chain Management: An International Journal, Vol. 11 No. 3, pp. 241-248.

Knowledge@Wharton (2012), How Apple Made ‘Vertical Integration’ Hot Again - Too Hot, Maybe, Business Time, available at: http://business.time.com/2012/03/16/how-apple-made-verticalintegration-hot-again-too-hot-maybe/ (accessed 4 March 2013). 
Kraljic, P. (1983), "Purchasing must become supply management", Harvard Business Review, Vol. 61 No. 5, pp. 109-117.

Kuo, T.C., Chang, S.H. and Huang, S.N. (2009), "Due-date performance improvement using TOC's aggregated time buffer method at a wafer fabrication factory", Expert Systems with Applications, Vol. 36 No. 2, pp. 1783-1792.

Lafontaine, F. and Slade, M. (2007), "Vertical integration and firm boundaries: the evidence", Journal of Economic Literature, Vol. 45 No. 3, pp. 629-685.

Lai, F., Zhang, M., Lee, D.M.S. and Zhao, X. (2012), "The impact of supply chain integration on mass customization capability: an extended resource-based view", IEEE Transactions on Engineering Management, Vol. 59 No. 3, pp. 443-456.

Langenberg, K.U., Seifert, R.W. and Tancrez, J.-S. (2012), "Aligning supply chain portfolios with product portfolios", International Journal of Production Economics, Vol. 135 No. 1, pp. 500-513.

Lee, H. (2004), “The triple - a supply chain”, Harvard Business Review, Vol. 82 No. 10, pp. 102-113.

Lee, H.L. (2002), "Aligning supply chain strategies with product uncertainties”, California Management Review, Vol. 44 No. 3, pp. 105-119.

Lee, H.L., Padmanabhan, V. and Whang, S. (2004), "Information distortion in a supply chain: the bullwhip effect”, Management Science, Vol. 50 No. S12, pp. 1875-1886.

Li, L. (2007), Supply Chain Management: Concepts, Techniques and Practices Enhancing Value Through Collaboration, World Scientific Publishing, available at: www.worldscientific.com/ worldscibooks/10.1142/6273\#t=toc (accessed 20 March 2014).

Li, S., Ragu-Nathan, B., Ragu-Nathan, T.S. and Subba Rao, S. (2006), "The impact of supply chain management practices on competitive advantage and organizational performance", Omega, Vol. 34 No. 2, pp. 107-124.

Li, X., Chung, C., Goldsby, T. and Holsapple, C. (2008), "A unified model of supply chain agility: the work-design perspective", International Journal of Logistics Management, Vol. 19 No. 3, pp. 408-435.

Lieberman, M.B. and Asaba, S. (2006), "Why do firms imitate each other?", Academy of Management Review, Vol. 31 No. 2, pp. 366-385.

Lok, P. and Crawford, J. (2004), "The effect of organisational culture and leadership style on job satisfaction and organisational commitment: a cross-national comparison", Journal of Management Development, Vol. 23 No. 4, pp. 321-338.

Lowson, R.H. (2001), "Retail operational strategies in complex supply chains", International Journal of Logistics Management, Vol. 12 No. 1, pp. 97-111.

Luo, X., Wu, C., Rosenberg, D. and Barnes, D. (2009), "Supplier selection in agile supply chains: an information-processing model and an illustration", Journal of Purchasing \& Supply Management, Vol. 15 No. 2009, pp. 249-262.

McDonald, J.M. (1985), "Market exchange or vertical integration: an empirical analysis", Review of Economics \& Statistics, Vol. 67 No. 2, pp. 327-332.

McKelvie, A., Haynie, J.M. and Gustavsson, V. (2011), "Unpacking the uncertainty construct: implications for entrepreneurial action”, Journal of Business Venturing, Vol. 26 No. 3, pp. 273-292.

Marquez, A.C. and Blanchar, C. (2004), "The procurement of strategic parts. analysis of a portfolio of contracts with suppliers using a system dynamics simulation model", International Journal of Production Economics, Vol. 88 No. 1, pp. 29-49.

Martensen, A., Gronholdt, L. and Kristensen, K. (2000), "The drivers of customer satisfaction and loyalty: cross-industry findings from Denmark", Total Quality Management, Vol. 11 Nos 4-6, pp. 544-553.

Martinez, M.T., Fouletier, P., Park, K.H. and Favrel, J. (2001), "Virtual enterprise - organization, evolution and control", International Journal of Production Economics, Vol. 74 No. 2001, pp. 225-238. 
Mellat-Parast, M. and Spillan, J.E. (2014), "Logistics and supply chain process integration as a source of competitive advantage", The International Journal of Logistics Management, Vol. 25 No. 2, pp. 289-314.

Milner, J.M. and Rosenblatt, M.J. (2002), "Flexible supply contracts for short life-cycle goods: the buyer's perspective", Naval Research Logistics (NRL), Vol. 49 No. 1, pp. 25-45.

Miltenburg, J. (2008), "Setting manufacturing strategy for a factory-within-a-factory", International Journal of Production Economics, Vol. 113 No. 1, pp. 307-323.

Moses, A. and Ahlstrom, P. (2008), "Problems in cross-functional sourcing decision processes", Journal of Purchasing \& Supply Management, Vol. 14 No. 2008, pp. 87-99.

Nachiappan, S. and Jawahar, N. (2008), "Pricing in supply chain under vendor managed inventory", in Kordic, V. (Ed.), Supply Chain Theory and Applications, I-Tech Education and Publishing, Vienna, pp. 387-426.

Nachiappan, S. and Jawahar, N. (2014), "Supply chain complexity and strategy", in Nachiappan, S. and Jawahar, N. (Eds), Supply Chain Strategies, Issues and Models, Springer, London, pp. 1-27.

Narayana, S.A., Pati, R.K. and Vrat, P. (2014), "Managerial research on the pharmaceutical supply chain - a critical review and some insights for future directions", Journal of Purchasing \& Supply Management, Vol. 20 No. 2014, pp. 18-40.

Naylor, J.B., Naim, M.M. and Berry, D. (1999), "Leagility: integrating the lean and agile manufacturing paradigms in the total supply chain", International Journal of Production Economics, Vol. 62 No. 1999, pp. 107-118.

Olhager, J. (2003), "Strategic positioning of the order penetration point", International Journal of Production Economics, Vol. 85 No. 3, pp. 319-329.

Park, T.Y., Choung, J.Y. and Min, H.G. (2008), "The cross-industry spillover of technological capability: Korea's DRAM and TFT-LCD industries", World Development, Vol. 36 No. 1, pp. 2855-2873.

Peck, H. (1998), Partnerships in the Supply Chain: Introducing Co-managed Inventory at Guinness GB, Council of Logistics Management, Oak Brook, IL.

Perrons, R.K. and Platts, K. (2005), "Outsourcing strategies for radical innovations: does industry clockspeed make a difference?", Journal of Manufacturing Technology Management, Vol. 16 No. 8, pp. 842-863.

Piplani, R. and Fu, Y. (2005), "A coordination framework for supply chain inventory alignment", Journal of Manufacturing Technology Management, Vol. 16 No. 6, pp. 598-614.

Ponomarov, S.Y. and Holcomb, M.C. (2009), "Understanding the concept of supply chain resilience", International Journal of Logistics Management, Vol. 20 No. 1, pp. 124-143.

Power, D. (2005), "Supply chain management integration and implementation: a literature review", Supply Chain Management: An International Journal, Vol. 10 No. 4, pp. 252-263.

Power, D., Sohal, A.D. and Rahman, S. (2001), "Critical success factors in agile supply chain management - an empirical study", International Journal of Physical Distribution \& Logistics Management, Vol. 31 No. 4, pp. 247-265.

Prahalad, C.K. and Hamel, G. (1990), "The core competence of the corporation", Harvard Business Review, Vol. 68 No. 3, pp. 79-91.

Qrunfleh, S. and Tarafdar, M. (2015), "Supply chain management practices - IT utilisation alignment: impact on supply chain performance and firm performance", International Journal of Business Information Systems, Vol. 18 No. 4, pp. 364-389.

Rahman, S. (2002), "The theory of constraints' thinking process approach to developing strategies in supply chains", International Journal of Physical Distribution \& Logistics Management, Vol. 32 No. 10 , pp. 809-828.

Ramanathan, U., Gunasekaran, A. and Subramanian, N. (2011), "Supply chain collaboration performance metrics: a conceptual framework”, Benchmarking: An International Journal, Vol. 18 No. 6, pp. 856-872. 
Ramsay, J. (2001), "The resource based perspective, rents, and purchasing's contribution to sustainable competitive advantage", Journal of Supply Chain Management, Vol. 37 No. 3, pp. 38-47.

Richey, R.G. Jr, Chen, H., Upreti, R., Fawcett, S.E. and Adams, F.G. (2009), "The moderating role of barriers on the relationship between drivers to supply chain integration and firm performance", International Journal of Physical Distribution and Logistics Management, Vol. 39 No. 10 , pp. 826-840.

Rossi, M., Tarba, S.Y. and Raviv, A. (2013), "Mergers and acquisitions in the hightech industry: a literature review", International Journal of Organizational Analysis, Vol. 21 No. 1, pp. 66-82.

Rumelt, R.P. (1984), "Towards a strategic theory of the firm”, in Lamb, R.B. (Ed.), Competitive Strategic Management, Prentice-Hall, Englewood Cliffs, NJ, pp. 556-571.

Sabath, R.E., Austry, C.W. and Daugherty, P.J. (2001), "Automatic replenishment programs: the impact of organizational structure”, Journal of Business Logistics, Vol. 22 No. 1, pp. 91-105.

Sharifi, H. and Zhang, Z. (2001), "Agile manufacturing in practice - application of a methodology", International Journal of Operations \& Production Management, Vol. 21 Nos 5-6, pp. 772-794.

Siemieniuch, C.E., Waddell, F.N. and Sinclair, M.A. (1999), "The role of 'partnership' in supply chain management for fast-moving consumer goods: a case study", International Journal of Logistics: Research and Applications, Vol. 2 No. 1, pp. 87-101.

Stavrulaki, E. and Davis, M. (2010), "Aligning products with supply chain processes and strategy", International Journal of Logistics Management, Vol. 21 No. 1, pp. 127-151.

Stevenson, M. and Spring, M. (2007), "Flexibility from a supply chain perspective: definition and review", International Journal of Operations \& Production Management, Vol. 27 No. 7, pp. 685-713.

Stratton, R. and Knight, A. (2010), "Managing patient flow using time buffers", Journal of Manufacturing Technology Management, Vol. 21 No. 4, pp. 484-498.

Stratton, R. and Warburton, R.D. (2003), "The strategic integration of agile and lean supply", International Journal of Production Economics, Vol. 85 No. 2, pp. 183-198.

Tallon, W.J. (1993), "The impact of inventory centralization on aggregate safety stock: the variable supply lead time case", Journal of Business Logistics, Vol. 14 No. 1, pp. 185-203.

Tang, C.S. (2006), "Robust strategies for mitigating supply chain disruptions", International Journal of Logistics: Research and Applications, Vol. 9 No. 1, pp. 33-45.

Trkman, P. and McCormack, K. (2009), "Supply chain risk in turbulent environments - a conceptual model for managing supply chain network risk", International Journal of Production Economics, Vol. 119 No. 2, pp. 247-258.

Tsanos, C.S., Zografos, K.G. and Harrison, Al. (2014), "Developing a conceptual model for examining the supply chain relationships between behavioural antecedents of collaboration, integration and performance", The International Journal of Logistics Management, Vol. 25 No. 3, pp. 418-462.

Tsay, A.A. and Lovejoy, W.S. (1999), "Quantity flexibility contracts and supply chain performance", Manufacturing \& Service Operations Management, Vol. 1 No. 2, pp. 89-111.

Umble, M., Umble, E. and Von Deylen, L. (2001), "Integrating enterprise resources planning and theory of constraints: a case study", Production and Inventory Management Journal, Vol. 42 No. 2, pp. $43-48$.

Umble, M. and Umble, E.J. (2006), "Utilizing buffer management to improve performance in a healthcare environment”, European Journal of Operational Research, Vol. 174 No. 2, pp. 1060-1075.

van der Vaart, T. and van Donk, D.P. (2008), "A critical review of survey-based research in supply chain integration", International Journal of Production Economics, Vol. 111 No. 1, pp. 42-55.

van der Vorst, J.G.A.J. and Beulens, A.J.M. (2002), "Identifying sources of uncertainty to generate supply chain redesign strategies", International Journal of Physical Distribution \& Logistics Management, Vol. 32 No. 6, pp. 409-430.

Van Donk, D.P. (2001), "Make to stock or make to order: the decoupling point in the food processing industries", International Journal of Production Economics, Vol. 69 No. 3, pp. 297-306. 
Van Hoek, R.I., Harrison, A. and Christopher, M. (2001), "Measuring agile capabilities in the supply chain”, International Journal of Operations \& Production management, Vol. 2 Nos 1-2, pp. 126-148.

Waller, M.M., Johnson, E. and Davis, T. (1999), "Vendor-managed inventory in the retail supply chain", Journal of Business Logistics, Vol. 20 No. 1, pp. 183-203.

Wang, E.T., Tai, J.C. and Wei, H.L. (2006), "A virtual integration theory of improved supply-chain performance”, Journal of Management Information Systems, Vol. 23 No. 2, pp. 41-64.

Williams, B.D., Roh, J., Tokar, T. and Swink, M. (2013), "Leveraging supply chain visibility for responsiveness: the moderating role of internal integration", Journal of Operations Management, Vol. 31 No. 7, pp. 543-554.

Wong, C.Y., Arlbjørn, J.S., Hvolby, H.-H. and Johansen, J. (2006), “Assessing responsiveness of a volatile and seasonal supply chain", International Journal of Production Economics, Vol. 104 No. 2, pp. 709-721.

Wong, W.K., Qi, J. and Leung, S.Y.S. (2009), "Coordinating supply chains with sales rebate contracts and vendor-managed inventory", International Journal of Production Economics, Vol. 120 No. 1, pp. 151-161.

Wu, C. and Barnes, D. (2011), "A literature review of decision-making models and approaches for partner selection in agile supply chains", Journal of Purchasing \& Supply Management, Vol. 17 No. 2011, pp. 256-274.

Wu, C. and Barnes, D. (2014), "Partner selection in agile supply chains: a fuzzy intelligent approach", Production Planning \& Control, Vol. 25 No. 10, pp. 821-839.

Wu, F., Yeniyurt, S., Kim, D. and Cavusgil, S.T. (2006), "The impact of information technology on supply chain capabilities and firm performance: a resource-based view", Industrial Marketing Management, Vol. 35 No. 4, pp. 493-504.

Wulf, K.D., Odekerken-Schröder, G. and Iacobucci, D. (2001), "Investments in consumer relationships: a cross-country and cross-industry exploration”, Journal of Marketing, Vol. 65 No. 4, pp. 33-50.

Yuan, K.J., Chang, S.H. and Li, R.K. (2003), "Enhancement of theory of constraints replenishment using a novel generic buffer management procedure", International Journal of Production Research, Vol. 41 No. 4, pp. 725-740.

Yusuf, Y.Y., Sarhadi, M. and Gunasekaran, A. (1999), "Agile manufacturing: the drivers, concepts and attributes”, International Journal of Production Economics, Vol. 62 Nos 1-2, pp. 33-43.

\section{Corresponding author}

Ehsan Sabet can be contacted at: e.sabet@lboro.ac.uk

For instructions on how to order reprints of this article, please visit our website: 